\title{
A Segmental Hypoplastic Anterior Tibial Artery Coexisting with a Hypertrophied Perforating Fibular Artery a Case Report and Clinical Implications
}

\author{
Coexistencia de una Arteria Tibial Anterior Hipoplásica Segmentaria con una \\ Arteria Fibular Perforante Hipertrofiada. Reporte de Caso e Implicancias Clínicas
}

\author{
Olutayo Ariyo*
}

\begin{abstract}
ARIYO, O. A segmental hypoplastic anterior tibial artery coexisting with an hypertrophied perforating fibular artery a case report and clinical implications. Int. J. Morphol., 33(1):19-23, 2015.

SUMMARY: Vascular injuries of the lower limb, especially from penetrating gunshot wounds, and peripheral arterial diseases are on the increase and management of these and many other lower limb injuries involve increasing usage of vascular interventions like by-pass surgery, per-cutaneous transluminal angioplasty, arterial cannulation, arterial bypass graft or minimally invasive measures like percutaneous trans-arterial catheterization, among others. A thorough knowledge of infrapopliteal branching most especially their pathways and luminal diameters are important to surgeons in selecting appropriate surgical interventions or procedures. We report the case in which one of the 3 terminal branches of the popliteal artery (PPA), the anterior tibial artery (ATA) of good caliber size at origin became hypoplastic in the anterior leg region after giving off numerous muscular branches. Continuing as an almost attenuated dorsalis pedis artery (aDPA) in the dorsum of the foot, the latter was reinforced by an enlarged hypertrophied fibular artery. This case illustrates yet the importance of the fibular artery as the dominant of the 3 infrapopliteal branching arteries, reinforcing or replacing the posterior tibial artery (PTA) when it is weak or absent by a strong communicating branch or, reinforcing a weak ATA and dorsalis pedis artery (DPA) by a strong perforating fibular artery as being reported. The PTA however travelled a normal course yielding the medial and lateral plantar arteries posterior to the abductor hallucis muscle. This case demonstrates the importance of collateral communications and reinforcements from other infrapopliteal arteries, whenever one of its members or subsequent branches are absent or hypoplastic. A very sound knowledge of the various branching patterns of the PPA can be gained via pre-operatively vascular angiography, designed to guide the surgeon in the selection of appropriate surgical interventions, adding value to patients care in helping to reduce iatrogenic surgical vascular complications and reduction in total number of limb loss.
\end{abstract}

KEY WORDS: Segmental hypoplastic anterior tibial artery; Attenuated dorsalis pedis artery; Hypertrophied fibular artery; Infrapopliteal branching.

\section{INTRODUCTION}

The popliteal artery is the continuation of the femoral artery beginning from the adductor hiatus. The artery descended laterally, crosses the popliteal fossa ending at the distal border of the popliteus where it divides to give the 3 infrapopliteal terminal branches, the anterior tibial artery (ATA), the posterior tibial/peroneal trunk (PTPT), the latter in turn gives rise to the peroneal artery about $2.5 \mathrm{~cm}$ distal to the ATA. The latter runs in the fibrous canal between the tibialis posterior muscle and the flexor hallucis longus. Embryologically, the sciatic artery is the embryonic vessels that supply the lower limbs. Arising from the dorsal root of the umbilical artery, the sciatic runs through the thigh, knee and leg, lying between the tibia and popliteus. A perforating branch that communicates with the femoral artery arises from the distal border of popliteus. This branch called ramus communicans passes ventrally between fibular and the tibia to form the anterior tibial artery (Ali \& Mohajir, 1996; Brantley et al., 1983). Persistent primitive arteria (PPA); segments, abnormal fusions, segmental hypoplasia or the absence of these arteries gave rise to anatomic variability. Variations in the pattern of the PPA revolve around the "high division" of that trunk (Keen, 1961) and the resulting differences in the arrangements of its terminal branches. The frequency of occurrence of "high division" of the popliteal artery are $4.4 \%$ (Poirier \& Charpy, 1899), about 5\% (Trotter, 1940), 2.5\% (Adachi, 1928), while Keen found 14 times in

${ }^{*}$ Thomas Jefferson Medical College, Thomas Jefferson University, Philadelphia, USA. 
280 limbs corresponding to $5 \%$. Trifurcation, is a popliteal arterial pattern where all the 3 arteries may arise from the termination of the popliteal at exactly the same level or as long as the point of origin of the peroneal artery is $5 \mathrm{~mm}$ or less from the main bifurcation (Adachi). Sometimes the PPA splits into 2 trunks, an ATA/Peroneal (Fibular) and posterior tibia trunk (PTT). Infrapopliteal collaterals do exist between the branches of the 3 major infrapopliteal arteries that do communicate to give vascular supply when one of these branches are weak or absent. Such collaterals exist between the PA and the ATA via the perforating fibular artery, between the peroneal and PTA via a communicating branch.

\section{CASE REPORT}

During routine academic anatomic dissection at Thomas Jefferson Medical College of Thomas Jefferson University dissecting facilities, a very careful review of a pre-dissected lower limb by the undergraduate medical students, we observed that in the popliteal fossa, the infrapopliteal vessels were seen to be normal, yielding an initial 2 trunks, a lateral one, which was the trunk to the ATA, and a medial one, the posterior tibial and peroneal trunk (PTPT) which branched shortly to give the (PTA)

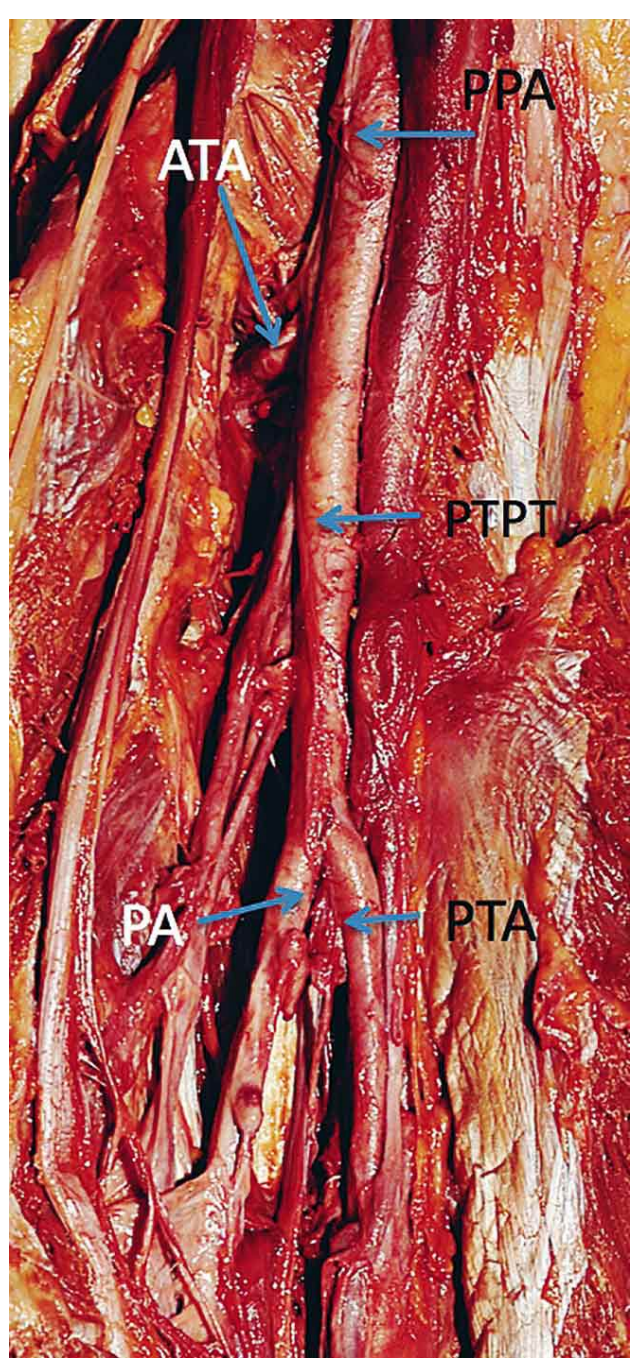

Fig. 1. This image shows the popliteal artery dividing to give it's terminal 3 branches, the anterior tibial, and common posterior tibial peroneal trunk which later divided to give fibular/peroneal artery and posterior tibia artery. At origin, all 3 vessels including the anterior tibial artery tend to be of good caliber size. PPA= popliteal artery, ATA= anterior tibial artery, $\mathrm{PTPT}=$ posterior tibial-peroneal trunk, FA/PA= fibular/ (peroneal) artery, $\mathrm{PTA}=$ posterior tibial artery.

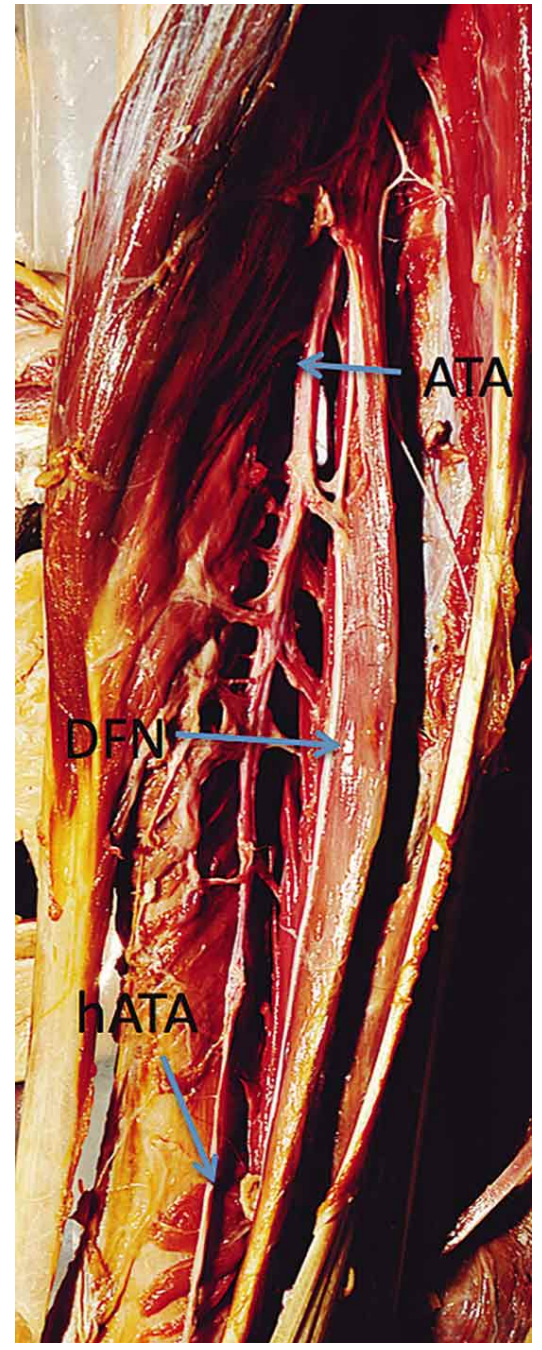

Fig. 2. This image shows the anterior tibial artery travelling with the deep fibular nerve in the extensor compartment of the leg. The anterior tibial artery was of a good size proximally, but as it journeys inferiorly, it gives several muscular branches, becoming very hypoplastic. ATA= anterior tibial artery, $\mathrm{DFN}=$ deep fibular nerve. $\mathrm{hATA}=$ hypoplastic anterior tibial artery. and the PA (Fig. 1). Both the PTA and PA travelled normally in the posterior leg, the PTA travelled with the tibial nerve and distally bifurcated posterior to abductor halluces giving the lateral and medial plantar arteries. The ATA however gave several robust muscular branches, became hypoplastic and on the dorsum of the foot. An hypertrophied perforating fibular artery was observed going through the intermuscular membrane to reach the dorsum of the foot (Fig. 2).

We observed the popliteal artery (PPA) ending normally at about the distal border of the popliteus muscle, where it divided to give the ATA and a PTPT, and at $2.5 \mathrm{~cm}$ distal to the ATA, this trunk bifurcated yielding an PA laterally and the PTA medially. None of the immediate branches of the popliteal artery, ATA, PTA and PA at origin was hypoplastic (Fig. 1). The ATA was of a good caliber size at origin (about 2.6 $\mathrm{mm}$ in diameter), passes through the oval aperture in the proximal part of the interosseous membrane to reach the extensor compartment where we observed the ATA supplying very prominent muscular branches to muscles in the anterior leg compartment (Fig. 2). 
Following the giving off of the muscular branches, the ATA became progressively smaller becoming more and more hypoplastic (Fig. 2), and by the time it crossed the ankle joint, it has become very attenuated and continued as an almost aplastic dorsalis pedis artery (aDPA) (Fig. 2). On the dorsum of the foot, we observed an hypertrophied perforating fibular artery (HPFA) traversing the interosseous membrane to enter the extensor compartment. The HPFA divided into medial and lateral branches (Fig. 3). The medial branch was the replacement vessel for the DPA while the lateral branch was joined by a small twig from the aDPA both skirting regions normally supplied by the arcuate arteries and its branches (Fig. 3). In the extensor compartment of the leg, we did not observe any muscular abnormalities, and no evidence of wasting or hypertrophy of muscles located on the dorsum of the foot and no evidence of hypertrophy, The deep fibular nerve (DFN) maintained the

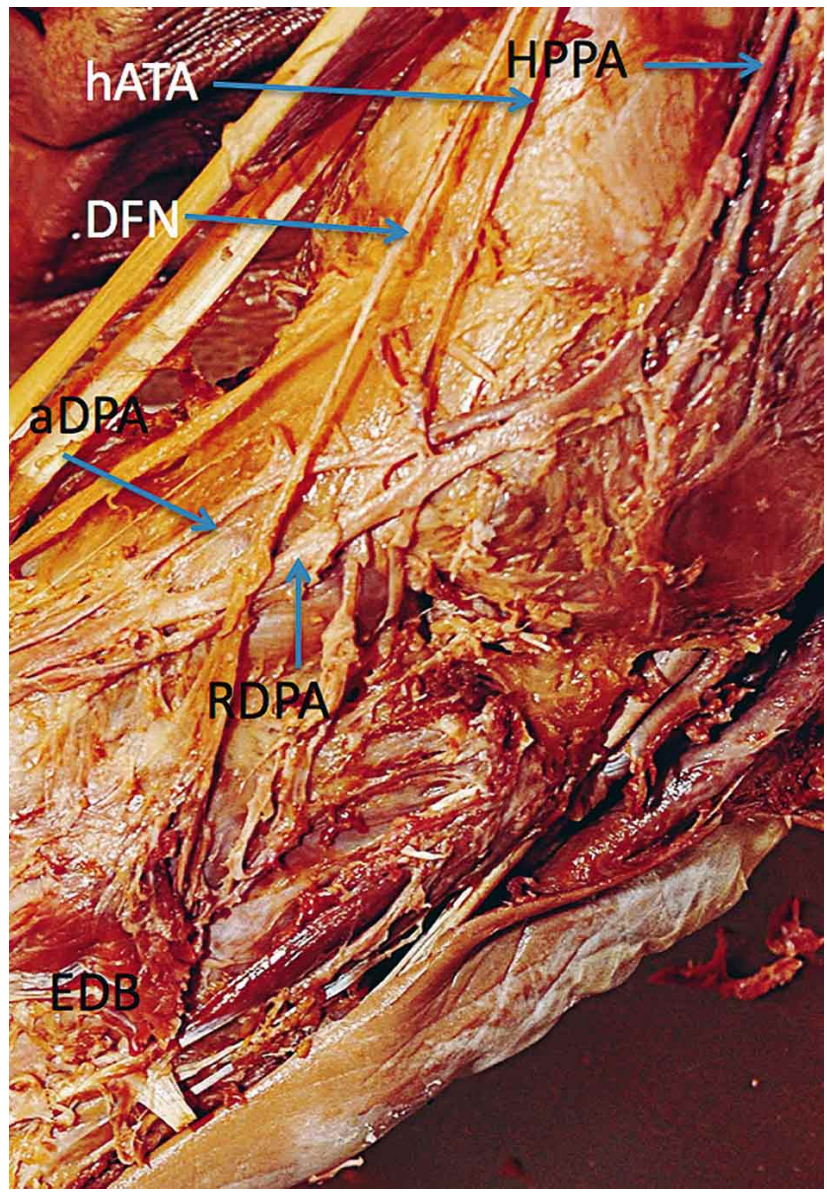

Fig. 3. This image shows the hypoplastic anterior tibial artery crossing the ankle joint, and becoming an attenuated dorsalis pedis artery in the foot. An enlarged/hypertrophied perforating fibular artery is observed emanating from the interosseus membrane and serves as the replaced dorsalis pedis artery in the dorsum of the foot. hATA= hypoplastic anterior tibial artery, aDPA= attenuated dorsalis pedis artery, $\mathrm{HPFA}=$ perforating fibular artery, $\mathrm{rDPA}=$ reinforcing dorsalis pedis artery, $\mathrm{EDB}=$ extensor digitorum brevis. same relationship with the ATA, travelling together anterior to the interosseus membrane, The PTA branching pattern was observed normal, bifurcating posterior to the abductor hallucis to give the medial and lateral plantar arteries. Neither of the plantar arteries was abnormal in size as observed visually even though the lateral plantar was observed bigger and was the main participant of the deep plantar arch, receiving a communicating branch from the HPFA. The PPA and its infra popliteal branching patterns in the R lower limb were normal.

\section{DISCUSSION}

Reported variants of the popliteal artery are many. The artery may divide into its terminal branches proximal to popliteus in which case the (ATA) sometimes descend anterior to the muscle. The size of the peroneal artery is said to be usually inversely related to the size of the anterior and posterior tibial arteries, either of which function the PA may assume (Standring, 2008). Variations in the pattern of the PPA revolve around the high division of that trunk. This high division was described as "at a level above the middle of the posterior surface of the popliteus muscle" (Adachi). Another variant of the popliteal artery pattern is "trifurcation". In the latter all the 3 terminal branches arise together at the inferior border of the popliteus muscle. Keen reported observing a trifurcation of the PPA in 12 of dissected yielding an incidence rate of $4.3 \%, 4.4 \%$ (Poirier \& Charpy), $5.5 \%$ (Trotter), $2.8 \%$ (Adachi). Kropman et al. (2011) reported that the 3 most frequent variations in branching of the popliteal artery are a high origin of the ATA, the trifurcation of the PPA and a hypoplastic or aplastic PTA. Some reported important characteristics of the ATA are as follows: (A-F) (A). The greatest diameter of the ATA was characteristics of the trifurcation pattern (Dobbs et al., 2004). B) Of the of the three calf arteries, the ATA was the predominant vessel in a trifurcation and in subtypes with anterior tibioperoneal trunk (Lippert \& Pabst, 1985; Kim et al., 1989). C). An association has been found between ATA and bony malformations of the lower limbs (Hootnick et al., 1984). Hootnick et al., also concluded that in limbs that contain the remnant of a missing structure, that injury occurred after the mesenchyme was instructed to form that structure Such abnormalities are termed "post-specification" defects, these being in contrast to those described as "pre-specification" malformations, of which a duplicated artery is an example of the latter, where the injury affected the signal before the instruction of the mesenchyme to develop into a specific structure was completed. (D). The luminal diameter of the ATA is the most important determination of the patency 
rate in anterior femorotibial graft (Karmody et al., 1984; Kremen et al., 1986). E). The luminal diameters of the ATA closely correlated with the percentage of the threeyear patency rate for bypass (Karmody et al.; Kremen et al.) and the cumulative limsalvage (Karmody et al.). F) Popliteal arterial variants and the normative data for ATA are important in vascular surgery below the knee following an angiographic study of the ATA in patients with aortoiliac occlusive disease (Szpinda, 2005). It has been reported that on variant patterns of the foot, the most common variant was that in which supply to the distal PTA arose from the peroneal artery. Atanasova et al. (2011) also reported the case of an hypoplastic ATA, ending above the ankle joint and was replaced distally by a large branch from the PTA the latter crossing the lowest portion of interosseous membrane. In the case being reported, an attenuated DPA, a distal vessel from an hypoplastic ATA was reinforced by an hypertrophied perforating fibular artery The fibular artery represents a significant contributory vessel to the foot. A segmental hypoplastic. ATA is a very rare infrapopliteal variant, and its occurrence no doubt supports the hypothesis by Lohan et al. (2008), that trifurcation vessel imaging should be a prerequisite to fibular free flap harvesting.

Variation in DPA. Palpation of the DPA is essential, particularly in suspected cases of arterial disorders. The DPA is also subjected to variations. Tuncel et al. (1994) reported the case of a bilateral anomalous origin for dorsalis pedis arteries originating from the fibular arteries because of the hypoplastic nature of both anterior tibial arteries. The artery is recognized to play an important role in the microvascular surgery of the foot during replantation, reconstructions and repair due to its unique anatomical position and bountiful supply to the foot (Vijayalakshmi et al., 2011). A good knowledge of the infrapopliteal variants and their branching patterns are critical in assisting vascular, orthopedic and plastic surgeons in making well informed decisions before embarking on any surgical interventions in the lower limb. Pre-operative MR angiographic study of infrapopliteal vessels and its branches will assist in revealing the presence of any existing malformations that may have important bearing on the choice of appropriate surgical procedures.

\section{ACKNOWLEDGEMENTS}

The author would like to thank the giver of this body for her generosity, even after death continues to give contributions to human knowledge. Thanks to the medical students who made an initial partial dissection on the cadaver, the friendly and scholarly environment provided by the various authorities of the Department of Pathology, Anatomy and Cell Biology. The tireless efforts of David and Karen of the Medical Media Unit in taking the photographs are appreciated.

ARIYO, O. Coexistencia de una arteria tibial anterior hipoplásica segmentaria con una arteria fibular perforante hipertrofiada. Reporte de caso e implicacias clínicas. Int. J. Morphol., 33(1):19-23, 2015.

RESUMEN: Las lesiones vasculares de los miembros inferiores, especialmente las heridas penetrantes por arma de fuego y enfermedades arteriales periféricas, están en aumento. Su manejo, así como el de otras lesiones en los miembros inferiores, implican un mayor uso de intervenciones vasculares como la cirugía de by-pass, angioplastía transluminal percutánea, canulación arterial, injerto de derivación arterial o medidas mínimamente invasivas como el cateterismo transarterial percutáneo, entre otros. El conocimiento profundo de las ramificaciones infrapoplíteas, muy especialmente sus vías y diámetros luminales son importantes para los cirujanos en la selección de las intervenciones o procedimientos quirúrgicos apropiados. Presentamos un caso en el cual, una de las 3 ramas terminales de la arteria poplítea (APP), la arteria tibial anterior (ATA), de buen calibre en su origen se hizo hipoplásica en la región anterior de la pierna después de un desprendimiento de numerosas ramas musculares. Continuó como una arteria dorsal del pie (ADP) casi atenuada en el dorso del pie; esta última se vio reforzada por una amplia arteria fibular hipertrofiada. Este caso ilustra la importancia de la arteria fibular como dominante de las 3 ramificaciones de las arterias infrapoplíteas, un refuerzo o sustitución de la arteria tibial posterior (ATP) cuando es débil o está ausente, por una fuerte rama comunicante, o bien refuerzo de una débil ATA y ADP por una fuerte arteria fibular perforante como en el caso reportado. La ATP sin embargo tenía un trayecto con un curso normal generando las arterias plantares medial y lateral, posterior al músculo abductor del hállux. Este caso demuestra la importancia de las comunicaciones colaterales y refuerzos de otras arterias infrapoplíteas, cada vez que uno de sus componentes o ramas posteriores están ausentes o hipoplásicas. Un conocimiento detallado de los diferentes patrones de ramificación de la APP puede ser adquirido a través de una angiografía vascular previo a la cirugía, diseñada para guiar al cirujano en la selección de las intervenciones quirúrgicas adecuadas, agrega valor a la atención de los pacientes, ayuda a disminuir las complicaciones vasculares quirúrgicas iatrogénicas y reduce el número total de pérdidas de miembros inferiores.

PALABRAS CLAVE: Arteria tibial anterior hipoplásica segmentaria; Arteria dorsal del pie atenuada; Arteria fibular hipertrofiada; Ramificación infrapoplítea. 


\section{REFERENCES}

Adachi, B. Das Arteriensystem der Japaner. Vol. I. Kyoto, Verlag der Kaiserlich-Japanischen Universitat, Kenyusha Press, 1928. pp.8, 205.

Ali, M. W. \& Mohajir, A. M. Dorsalis pedis artery: variations and clinical significance. J. Indian Med. Assoc., 94(11):417-8, 1996.

Atanasova, M.; Georgiev, G. P. \& Jelev, L. Intriguing variations of the tibial arteries and their clinical implications. Int. J. Anat. Var., 4:45-7, 2011.

Brantley, S. K.; Rigdon, E. E. \& Raju, S. Persistent sciatic artery: embryology, pathology, and treatment. J. Vasc. Surg., 18(2):242-8, 1983.

Dobbs, M. B.; Gordon, J. E. \& Schoenecker, P. L. Absent posterior tibial artery associated with idiopathic clubfoot. A report of two cases. J. Bone Joint Surg. Am., 86-A(3):599-602, 2004.

Hootnick, D. R.; Packard, D. S. Jr.; Levinsohn, E. M.; Lebowitz, M. R. \& Lubicky, J. P. The anatomy of a congenitally short limb with clubfoot and ectrodactyly. Teratology, 29(2):15564, 1984

Karmody, A. M.; Leather, R. P.; Shah, D. M.; Corson, J. D. \& Naraynsingh, V. Peroneal artery bypass: a reappraisal of its value in limb salvage. J. Vasc Surg., 1(6):809-16, 1984.

Keen, J. A. A study of the arterial variations in the limbs, with special reference to symmetry of vascular patterns. Am. J. Anat., 108:245-61, 1961.

Kim, D.; Orron, D. E. \& Skillman, J. J. Surgical significance of popliteal arterial variants. A unified angiographic classification. Ann. Surg., 210(6):776-81, 1989.

Kremen, A. F.; Mendez-Fernandez, M. A.; Geis, R. C. \& Henly, W. S. The Dracon EXS graft: patency in femoropopliteal and femorotibia surgery. J. Cardiovasc. Surg. (Torino), 27(2):12530, 1986

Kropman, R. H.; Kiela, G.; Moll, F. L. \& de Vries, J. P. Variations in anatomy of the popliteal artery and its side branches. Vasc. Endovascular Surg., 45(6):536-40, 2011.

Lippert, H. \& Pabst, R. Arterial variations in man: classification and frequency. Munich, Bergman Verlag, 1985. pp.60-4.

Lohan, D. G.; Tomasian, A.; Krishnam, M.; Jonnala, P.; Blackwell, K. E. \& Finn, J. P. MR angiography of lower extremities at 3 $\mathrm{T}$ : presurgical planning of fibular free flap transfer for facial reconstruction. AJR Am. J. Roentgenol., 190(3):770-6, 2008.

Poirier, P. \& Charpy, A. Traité d'Anatomie Humaine. L. Paris, Masson, 1899. pp.734, 756, 822, 833.
Standring, S. Gray's Anatomy: The Anatomical Basis of Clinical Practice. $40^{\text {th }}$ ed. Philadelphia, Elsevier, 2008. pp.1344, 1408.

Szpinda, M. External diameters of the crural arteries in patients with chronic critical limb ischaemia. Folia Morphol. (Warsz.), 64(4):315-20, 2005.

Trotter, M. The level of termination of the popliteal artery in the White and the Negro. Am. J. Phys. Anthropol., 27(1):109-18, 1940.

Tuncel, M.; Mara, T.; Celik, H. \& Tasçioglu, B. A case of bilateral anomalous origin for dorsalis pedis arteries (anomalous dorsalis pedis arteries). Surg. Radiol. Anat., 16(3):319-23, 1994.

Vijayalakshmi, S.; Gunapriya, R. \& Varsha, S. Anatomical study of dorsalis pedis artery and its clinical correlations. J. Clin. Diagn. Res., 5(2):287-90, 2011.

\section{Correspondence to: \\ Olutayo Ariyo, MBBS, MBA \\ Thomas Jefferson Medical College \\ Thomas Jefferson University \\ Rm 263 F, JAH, 1020 Locust Street \\ Philadelphia, PA 19050 \\ USA}

Email: olutayo.ariyo@jefferson.edu

Received: 03-05-2014

Accepted: 24-10-2014 